\author{
Крюкова І.O. \\ доктор економічних наук, профресор \\ кафедра обліку і оподаткування \\ Одеський державний аграрний університет \\ вул. Пантелеймонівська, 13, м. Одеса, Україна, 65039 \\ E-mail: Kryukovaia1@rambler.ru \\ ORCID ID: 0000-0002-0577-6364
}

\title{
ВИРОБНИЧИЙ ПОТЕНЦІАЛ МОЛОКОПЕРЕРОБНИХ ПІДПРИЄМСТВ УКРАЇНИ У КОНТЕКСТІ ЄВРОІНТЕГРАЦІЙНОГО РОЗВИТКУ
}

У статті проведено аналіз виробничого потенціалу молокопереробних підприємств України, досліджено сучасний стан сировинної бази молокопродуктової галузі в контексті забезпечення внутрішніх потреб та окремих індикаторів продовольчої безпеки населення країни. Проаналізовано обсяг і структуру споживання молокопродуктів в Україні у порівнянні з країнами ЄС. Дана оцінка розвитку національного ринку молока і молокопродуктів в порівнянні з ключовими тенденціями європейського ринку. Проаналізовано особливості товарної структури молочної галузі України та європейських країн. Досліджено потенціал використання європейських квот на вітчизняну молокопродукцію, основні напрями та прогнози експорту молокопродуктів у країнах $Є С$, виявлено відмінності між обсягами державної фрінансової підтримки молочної галузі європейських країн та України. Результатами дослідження стало обґрунтування перспективних шляхів подальшого розвитку галузі та напрямів диференціації географрічної структури експорту для вітчизняних молокопереробних підприємств.

Ключові слова: виробничий потенціал, молокопереробні підприємства, молокопродукти, ринок молока та молокопродуктів, експорт.

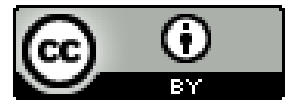

This work is licensed under a Creative Commons Attribution 4.0 International License http://creativecommons.org/licenses/by/4.0/

Постановка проблеми та її зв'язок з важливими науковими та практичними завданнями. Молокопродуктова галузь України, традиційно, постає однією з основних у сфері агропромислового виробництва, формує базис забезпечення продовольчої безпеки країни та $є$ перспективною з точки зору нарощування експортного потенціалу національної економіки. Проте, розвиток даної галузі за останні роки стримується низькою існуючих проблем, основною 3 яких $\epsilon$ неповне використання виробничого потенціалу, зумовлене скороченням обсягів поставок молочної сировини та негативними економічними тенденціями, які мають місце у молочному скотарстві. Після укладання Угоди про асоціацію між Україною та країнами СС для національної молокопродуктової галузі відкрились нові ринкові можливості. Проте, значний конкурентний тиск 3 боку європейських молочних компаній сьогодні вимагає детального аналізу можливостей, загроз і перспектив, які формує європейський ринок молокопродуктів для вітчизняних виробників.

Аналіз останніх публікацій по проблемі. Науково-практична проблематика сталого розвитку підприємств молокопродуктової галузі значний час постає у призмі уваги відомих вчених, теоретичний, методичний i практичний базис наукових праць яких формує потужний каркас вирішення цієї складної та актуальної проблеми сьогодення. Серед науковців, які зробити потужний внесок у розвиток визначеної проблеми, слід відмітити наступних: Бащенко M.I., Бойківська Г.М., Іщук С.О., Калинчик М.В., Лагодієнко В.В., Ларина Я.С., Ліпич Л.Г., Ляховська О.В., Малік М.Й., Месель-Веселяк В.Я., Мостенська Т.Л., Пархомець М. К., Пєтухова О.М., Погріщук Б.В., Россоха В.В., Саблук, В.М., Федулова I.В., Шевельова С.О. та інші. Проте, висока ступінь динамічності та загострення конкурентної боротьби, як на національному, так і на світовому ринку молока та молокопродуктів, зумовлюють необхідність подальших наукових досліджень у напрямі пошуку шляхів забезпечення сталого розвитку вітчизняної молокопродуктової галузі.

Формулювання цілей дослідження. Метою статті $\epsilon$ оцінка сучасного виробничого потенціалу молокопереробних підприємств України у контексті подальшого розвитку євроінтеграційних економічних зв'язків та перспектив заняття місця на європейському ринку молокопродуктів.

Виклад основних результатів та їх обгрунтування. Термін «виробничий потенціал» у науковій літературі використовується при характеристиці економічних процесів на різних рівнях господарського управління. Систематизація наукових підходів до трактування сутності і змісту виробничого потенціалу показала, що найчастіше його визначають як сукупність ресурсів (факторів виробництва) та економіч- 
ного ефекту від їх використання [1], як максимально можливий обсяг виробництва продукції певних якісних параметрів, як наявні (реальні) виробничі можливості бізнес-суб'єкта [2]. Основними елементами виробничого потенціалу виступають всі види ресурсів (матеріальні, нематеріальні, кадрові, фінансові, інформаційні), які $є$ необхідними для забезпечення основного виробничого процесу залежно від специфіки виду економічної діяльності [3].

Виробнича (ресурсна) складова постає базисом економічного потенціалу підприємства. За такого підходу виробничий потенціал можна охарактеризувати як здатність (наявність ресурсів і можливостей) до максимального випуску продукції з урахуванням системи факторів зовнішнього і внутрішнього середовища.

Разом 3 тим, сучасні умови господарювання вимагають доповнення ресурсної складової виробничого потенціалу, яка постає базисом економічного потенціалу, сукупністю чинників ринкового характеру, основних функцій i елементів організаційного i управлінського процесу, потенціалу маркетингу, які у сукупності взаємодіють як цілісна економічна система та формують можливості отримання майбутніх ринкових вигід бізнес-суб'єкта.

Виробничий потенціал підприємства визначається, в першу чергу, кількісними параметрами (обсягом виробництва продукції) та іiі якісними характеристиками (якість і конкурентоспроможність продукціі).

Виробничий потенціал молокопереробних підприємств визначається потенціалом сировинної бази аграрного виробництва - молочного скотарства. Традиційно, молочне скотарство вважалось стратегічної галуззю аграрної економіки, проте протягом останніх десятиріч, дана галузь опинилась практично на межі зникнення.

Упродовж 2014-2019 років обсяги виробництва молочної сировини зменшились на $15,68 \%$, в порівнянні $з$ 1990p. - на 60,6\%. За даними Державної служби статистики України обсяги виробництва молока всіма категоріями господарств у 2019р. склали 9,6 млн. т., 3 яких 28,2\% забезпечують сільськогосподарські підприємства та 71,8\% - господарства населення [4]. Основною причиною такого скорочення стало різке зменшення продуктивного поголів'я, темп зменшення якого у порівнянні з 1990р. склав 79\%. В основному, таке скорочення відбулось за рахунок сільськогосподарських підприємств, де скорочення чисельності корів склало 92,9\%. Станом на 2019p. чисельність корів у сільськогосподарських підприємств становила 438,6 тис гол. Більш повільними темпами скорочення чисельності поголів'я відбувається у господарствах населення - темп скорочення становив $38,3 \%$ [4].

Зменшення сировинної бази призвело до неповного використання виробничого потенціалу молокопродуктової галузі: в період з 2013р. по 2019p. обсяги виробництва готового молока та вершків зменшились на $12,6 \%$, сухого молока - на 7,2\%, вершкового масла - на 2,6\%, твердих сирів - на 44,1\%, йогу- ртів, кефіру, сметани - на25,9\%, морозива - на 9,9\% [5]. У підсумку, за цей період Україна втратила п’ять позицій у світовому рейтингу виробників сирого молока, посівши у 2019 році 19-те місце [6].

Обсяг виробництва молока в розрахунку на одну особу в Україні сьогодні складає 229,9 кг, середньорічний обсяг споживання молока та молокопродуктів населенням країни - 200,5 кг при нормі 360380 кг на особу за рік. Враховуючи нормативні потреби споживання молока та молочних продуктів, обсяги виробництва молока в України мають становить не менше 15 млн. тонн щорічно, що за середнього рівня продуктивності корів потребує нарощування поголів'я продуктивних корів, як мінімум, до 3014 тис гол. при фактичній їх чисельності у 2019p. 1788,5 тис. гол.

Традиційно, молочні продукти були присутні у складі експортного потенціалу національної економіки. За останні роки їх частка у структурі експорту товарами має тенденцію до скорочення. За підсумками 2013p. обсяги зовнішніх надходжень від експорту молока та молочних продуктів склали 691,7 млн. дол. США (1,1\%), у 2019p. - 119,7 млн. дол. США (0,9\%) [7].

За даними агропорталу, в Україні провідними компаніями - експортерами молочної продукції є: Вінницький молочний завод «Рошен», Мілкіленд Інтермаркет», «Яготинський маслозавод», «КомоЕкпорт», «Лаклалис-Україна», «Доменик», «Купянський молочноконсервний комбінат». Основними країнами, які імпортують українську молочну продукцію, $є$ : Молдова, Грузія, Лівія (молоко та вершки не згущені), Китай (молоко та вершки згущені), Казахстан (йогурти, вершки, кефір), Азербайджан, Молдова (масло вершкове, молочні жири, сири) [8].

Реалізація євроінтеграційної моделі розвитку національної економіки передбачає оцінку виробничого потенціалу вітчизняної молокопродуктової галузі у контексті із ключовими тенденціями розвитку ринку молокопродуктів Європейського союзу та оцінку можливих економічних альтернатив інших ринків збуту.

Серед 27 країн Свропейського Союзу, які є виробниками молока, найбільша питома вага у забезпеченні переробних підприємство молочною сировиною, є: Німеччина (близько 23,4\%), Франція - 18,2\%, Великобританія - близько 11\%, Італія - 8,9\% [9]. У рейтингу найкрупніших молочних компаній за річним оборотом перше місце вже не перший рік займає компанія Nestle (Швейцарія) із річним оборотом 24,3 млрд. дол. Друге місце займає молочна компанія Lactalis iз річним оборотом 20.8 млрд. дол., третє - Danone (18,0 млрд. дол.) [10].

Найбільшими операторами ринку молочної продукції в Україні сьогодні постають: «Данон» 13,5\%, «Молочний Альянс» - 11,2\%, «Лакталіс» 9,9\%, «Люстдорф»- 9,8\%, «Вімм-Біль-Данн» - 8,8\%, Придніпровський молочний комбінат - 5,5\%, «Галичина» - 5,3\%, Тернопільський молокозавод - 5,2\%, «Терра Фуд» - 4,7\% [11].Відміна механізму територіального квотування на молочну сировину призвела до 
подальшої інтенсифікації та модернізації молочних ферм у СС, орієнтацію на найбільш продуктивні породи ВРХ молочного напрямку (переважно фризькоголштинських порід). Середній рівень продуктивності корів у країнах ЄС у 2019p. склав 7346 кг при найвищому іiі рівні у Данії - 9973 кг, Естонії - 9656 кг, Іспанії - 9178 кг. Найнижчий рівень продуктивності корів спостерігається у Болгарії - 3627 кг та Румунії3217 кг. [9]. В Україні середньорічний надій молока на одну корову становить 4976кг (6101 кг у підприємствах та 4630 кг в господарствах населення) [4].

Обсяг внутрішнього споживання молочної сировини на європейських фермах має тенденцію до скорочення (частка молока, спожитого у межах ферм, складає близько 7,6\%). Загальний обсяг виробництва молока у країнах ЄС у 2019p. склав 158,3 млн. тонн. В цілому, за даними Свростату, структура молочного виробництва на європейському ринку представлена наступним чином: 96\% - коров'яче молоко, 1,9\% молоко овець (Іспанія, Італія), 1,6\% - козяче молоко (Іспанія, Італія, Франція, Греція, Кіпр), 0,2\% - буйволяче молоко. Загальний обсяг надходжень молочної сировини на молокопереробні підприємства європейських країн (рис. 1) становив 147,9 млн. т, з яких 2,5 млн. т склала імпортна молочна сировина [9].

В Україні обсяги надходження молочної сировини на переробні підприємства за 2015-2017pр. скоротились в чотири рази і становили 1,2 млн. тонн (0,8\% у структурі промислової переробки молока по країнах $(\mathrm{C})$.

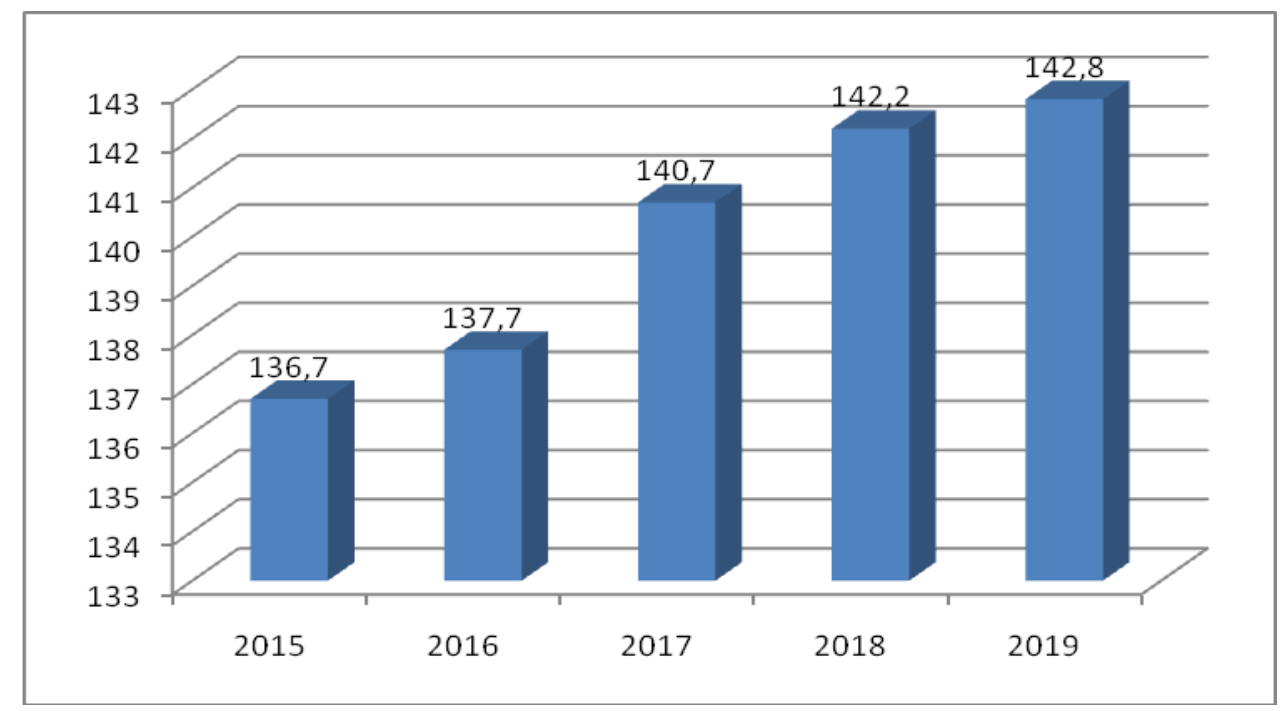

Рис. 1. Обсяги надходження молочної сировини на переробні підприсмства країн СС, млн. тонн*

* сформовано автором на основі даних Свростату

У структурі готової продукції європейських молокопереробних підприємств молоко займає близько $23,4 \%, 14,8 \%$ - йогурти, сири - 1,01\%, масло вершкове - 2,3\%, сухе молоко - 3,0\%, молокопродукти в еквіваленті рідкої сироватки - 54,8\% [9]. У структуpi виробництва молокопродуктів в Україні домінує молоко питне - 43\%, кисломолочні продукти $-20,4 \%$, морозиво - 9,6\%, сири - 9,3\%, сироватка - 5, $1 \%$, масло вершкове - 4,5\%, вершки - 3,2\% [5]. Разом 3 тим, на вітчизняному ринку молокопродуктів спостерігається значне нарощування обсягів європейської молочної продукції, зокрема, сирів. Основними країнами-експортерами європейської молочної продукції сьогодні є: вершкове масло - США, Китай, Саудівська Аравія, Марокко, сири - США, Японія, Швейцарія, Південна Корея, інші молокопродукти - Китай, Алжир, Нігерія, Індонезія, Сгипет [9].

Угодою про асоціацію між Україною та ЄС було встановлено графік скасування ввізних мит на товари з урахуванням використання певних кількісних квот. Починаючи з 2019p. у відповідності до графіку сума увізних мит становить $0 \%$. Найбільшими обсягами поставок на європейський ринок серед всіх видів молокопродуктів відрізняється вершкове масло, квоти на його експорт у 2019р. були використані в повному обсязі. Обсяг квот на експорт молокопродуктів з України до європейського ринку на 2021р. були визначені на такому рівні: вершкове масло - 3000т, сухе молоко - 5000т, молоко, вершки, згущене молоко та йогурти - 10000т, сметана - 500т, сир кисломолочний та морозиво - 2000т. Такі квоти є невідповідними виробничому потенціалу вітчизняної молокопродуктової галузі. У 2019p. квота на експорт сухого молока до ЄС виконана на 30\%, на продукцію 3 незбираного молока - на 15\%, сир кисломолочний, морозиво - на $39 \%$, продукції з вершків - на $2 \%$, спредів $-0 \%$ [12].

Разом з тим, на українському ринку різко зростає частка європейських молокопродуктів, зокрема, сирів (до 30\%). Основними слабкими позиціями вітчизняної молокопродукції постає асортимент продукції, ціни, якість та відомість брендів. 3 урахуванням сучасних тенденцій, країни Європейського союзу постають не потенційним ринком збуту українських молокопродуктів, а конкурентами вітчизняних компаній на українському молочному ринку.

Потужний механізм державної фінансової підтримки виробників молочної продукції в країнах СС 
практично нівелює шанси українських виробників на рівну конкурентну боротьбу на європейському ринку молокопродуктів. У країнах СС фермери отримують дотації в розмірі 13-14 євроцентів на літр при собівартості виробництва 43-44 євроценти. Крім того, ПДВ на продукти харчування в СС становить 7\% проти $20 \%$ в Україні. Польща протягом 2003-2018 років отримала на розвиток молочної галузі 29 млрд. євро (в середньому близько 1,9 млрд. євро на рік), Німеччина - 64 млрд. євро (4,3 млрд. євро на рік). [13] В Україні за 2019p. в рамках державних фінансових програм підтримки галузі тваринництва було надано 299,9 млн. грн. на відшкодування вартості закуплених племінних тварин, 430,5 млн. грн. часткового відшкодування вартості будівництва (реконструкції) тваринницьких ферм і комплексів, доїльних залів, підприємств 3 переробки сільськогосподарської продукції, 770,9 млн. грн. для надання часткової компенсації вартості будівництва (реконструкціі) тваринницьких ферм і комплексів, в частині витрат, профінансованих без урахування податку на додану вартість за рахунок банківських кредитів (близько 50 млн. євро за рік) [8]. Фактичні обсяги державної фінансової підтримки тваринництва в Україні не є співставними з розмірами фінансової допомоги у країнах $\mathrm{CC}$.

За даним вітчизняних експертів, для підтримки сталих темпів розвитку молочної галузі в Україні необхідно створити фінансовий механізм субсидування з урахуванням квотування державної фінансової підтримки молокопродуктів, зокрема: дотації на вершкове масло (до 100 грн. за 1 кг), сухе знежирене молоко - до 40 грн. за 1кг), субсидування експорту до 300 дол. США в розрахунку на 1 тону експортованого сухого знежиреного молока [14]. Збільшення розміру дотацій та субсидій на молочне скотарство сьогодні є однією з основних передумов нарощування виробничого потенціалу вітчизняної молокопродуктової галузі.

За даними світових експертів (FАO), ринок молока та молочних продуктів має значний потенціал зростання (в середньому до 1,6\% на рік до 997 млн. т у 2029p.). Європейський ринок буде зростати більш повільними темпами внаслідок обмеженого внутрішнього попиту та екологічних і технологічних обмежень виробництва. За прогнозами, найбільш привабливими 3 точки зору зростання попиту на молочну продукцію в найближчі 10 років стануть країни Африки, Індія, Пакистан. Свропейський ринок $з$ позицій попиту та ємкості залишиться стабільним. Разом 3 тим, спостерігається зростання обсягів попиту та місткості ринку органічного молока (до 10\% загального виробництва), яке на сучасному етапі розвитку становить близько $3 \%$. Крім того, прогнозним є зростання внутрішнього європейського попиту на такі молочні продукти, як: масло, сир, вершки, екойогурти [15].

Європейський Союз сьогодні, поряд із США та Новою Зеландією, є одним з найбільших експортерів молока та молочної продукції. За даними [16] серед світових компаній, які є лідерами у виробництві молока у світі (рейтинг 10 найкрупнішіх компаній), провідне місце займають молочні компанії США та Китаю: Almarai (Саудівська Аравія), Modern Dairy (Китай), Rockview (США), Riverview (США), Faria Brothers (США), Econiva (Росія), Huishan Dairy (Китай), Shengmu (Китай), Seikexing (Китай), Yili Youran (Китай) [16].

За даними середньострокового прогнозу Комісії $€ \mathrm{C}$ з сільськогосподарських ринків та доходам на період до 2030p. основним імпортером молочних продуктів залишиться Китай. При цьому, частка ЄС у забезпеченні сукупного попиту має становити не менше $30 \%$. За прогнозами у Свропейських країнах зменшиться споживання свіжого молока, яке займає переважну частку у структурі виробництва молочної продукції в Україні. Очікується також збільшення обсягів органічного молоковиробництва.

Враховуючи сучасні світові тенденції розвитку ринку молока і молокопродуктів перспективними для України постають не країни $\mathrm{CC}$, які, потенційно, можуть і надалі залишатись провідними стратегічними торговельними партнерами України, а країни Близького Сходу, Північної Африки, Китай. За сучасних економічних реалій країни цих регіонів постають найбільш привабливими ринками збуту молокопродуктів, на яких Україна може мати стратегічні передумови конкурентоспроможності, пов'язані як $з$ географічними так і $з$ економічними чинниками. Вирішення завдання освоєння нових ринків збуту має відбуватись за умов термінового відродження вітчизняної молочної галузі і нарощування виробничого потенціалу молочного скотарства та набуття пріоритетності у сфері дії механізму державної фінансової підтримки українського агробізнесу.

Висновки та перспективи подальших досліджень. Основними напрямами розвитку вітчизняної молочної галузі мають стати досягнення конкурентних переваг за рахунок оптимізації витрат, розширення товарного асортименту продукції, покращення iii якісних параметрів. 3 метою досягнення світових конкурентних переваг необхідним $€$ нарощування обсягів органічного молочного скотарства та органічної переробки молочної сировини.

Волатильність національного і світового ринку вимагає від виробників забезпечення тактики і стратегії сталого розвитку, реалізації превентивних заходів буферного захисту від цінових коливань та підвищення економічної стійкості від дії ринкових факторів бізнес-середовища. Пріоритетними стратегічними орієнтирами подальшого розвитку молокопереробних підприємств України у маркетинговому вимірі мають бути географічна та товарна диверсифікація, здобуття конкурентних переваг за рахунок цінового фактору, формування привабливого для вітчизняного та світового споживача товарного асортименту та активізація брендингової політики. Перспективами подальших наукових досліджень постає вивчення тенденцій та особливостей молочного ринку країн Близького Сходу та Північної Африки (MENA) як перспективного напряму експорту українських молокопродуктів. 


\title{
Література
}

1. Россоха В.В. Формування і розвиток виробничого потенціалу аграрних підприємств: монографія. Київ: ННЦ: ІАЕ, 2009. 444c.

2. Бойківська Г. Напрями підвищення ефективності використання виробничого потенціалу переробних підприємств системи АПК: монографія. Тернопіль: Крок, 2012. 238 с.

3. Запащук Л.В. Методичні підходи до оцінки виробничого потенціалу промислового підприємства // Вісник ЖДТУ, 2010. № 3(53). С. 60-63.

4. Тваринництво України. 2019: стат зб. / Держ. служба статистики України. Київ, 2019. URL: http://ukrstat.gov.ua/druk/publicat/kat_u/2020/zb/05/zb_tvaryny_2019.pdf (дата звернення 09.01.2021).

5. Виробництво промислової продукції за видами: 2019: стат зб. / Держ. служба статистики України. Київ, 2019. URL: http://ukrstat.gov.ua (дата звернення 09.01.2021).

6. Іщук С.О., Ляховська О.В. Проблеми і перспективи розвитку молокопереробних виробництв в Україні: регіональний вимір. Львів, 2020. 32с.

7. Зовнішня торгівля України. 2019: стат зб. / Держ. служба статистики України. Київ, 2019. URL: http://ukrstat.gov.ua/druk/publicat/kat_u/2018/zb/09/zb_sg2019_pdf.pdf. (дата звернення 10.01.2021).

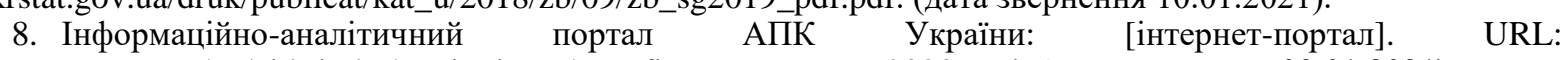
https://agro.me.gov.ua/ua/pidtrimka/tvarinnictvo/stan-finansuvannya-u-2020-roci. (дата звернення 09.01.2021).

9. Agriculture, forestry and fishery statistics. Statistical Books / Eurostat, 2020. URL: https://ec.europa.eu/eurostat/documents/3217494/12069644/KS-FK-20-001-EN-N.pdf/a7439b01-671b-80ce-85e44d803c44340a?t=1608139005821 (дата звернення 05.01.2021).

10. The Dairy News. Rabobank представил топ-20 молочных компаний мира в 2019 году. URL: https://www.dairynews.ru/news/rabobnk-predstavil-top-20-molochnykh-kompaniy-mira.html. (дата звернення 05.01.2021).

11. ТОП - 10 українських виробників молочної продукції. MilkUa: веб-сайт. URL: http://milkua.info/uk/post/top-10-ukrainskih-virobnikiv-molocnoi-produkcii (дата звернення 05.01.2021).

12. Україна мляво вибирає квоти на експорт молочної продукції до ЄC. Агротайм: веб-сайт. URL: https://agrotimes.ua/tvarinnitstvo/ukrayina-mlyavo-vybyraye-kvoty-na-eksport-molochnoyi-produkcziyi-do-yes/ (дата звернення 05.01.2021).

13. Пирожок О. Дорожче, ніж у Брюсселі: як українське молоко програє Україну виробникам СС. Економічна правда: веб-сайт. URL:https://www.epravda.com.ua/rus/publications/2019/12/2/654311 (дата звернення 09.01.2021).

14. Чагаровський В. Щороку в Україні зникає 1 велике молокопереробне підприємство. URL: https://agropolit.com/interview/748-vadim-chagarovskiy-schoroku-v-ukrayini-znikaye-1-velike-molokopererobnepidpriyemstvo (дата звернення 09.01.2021).

15. Dairy and dairy products. OECD-FAO AGRICULTURAL OUTLOOK 2020-2029. URL: http://www.fao.org/3/ca8861en/Dairy.pdf (дата звернення 10.01.2021).

16. Shahbandeh M. Leading dairy farming companies worldwide in $2018 / 2019$, based on raw milk production. URL:https://www.statista.com/statistics/1124669/leading-dairy-farming-companies-based-on-milkproduction (дата звернення 05.01.2021).

Стаття надійшла 20.01.2021

Стаття прийнята до друку 3.02.2021

Доступно в мережі Internet 18.04.2021

\author{
Kryukova I. \\ Doctor of Economics, Professor \\ Department of Accounting and Taxes \\ Odessa State Agrarian University \\ Panteleymonivska str, 13, Odessa, Ukraine \\ E-mail: Kryukovaia1@rambler.ru \\ ORCID ID: 0000-0002-0577-6364
}

\section{PRODUCTION POTENTIAL OF MILK-PROCESSING ENTERPRISES OF UKRAINE IN THE CONTEXT OF EURO-INTEGRATED DEVELOPMENT}

One of the strategic in the field of agro-industrial production is the dairy industry of Ukraine. It forms the basis for ensuring the country's food security and is promising from the standpoint of increasing the export potential of the national economy. At the same time, over the past decades, there has been a significant decrease in the use of the industry's production potential. This is characterized by a sharp decline in the production of raw milk and the main types of dairy products.

Today Ukraine is losing its position in the world and European dairy products market. Analysis of the structure and main trends of the EU countries' milk and dairy products market showed that Ukraine has practically no prospects for the supply of raw milk to the European market. The structure of finished products of 
dairy processing enterprises of the EU countries and Ukraine has significant differences. Today, the export of dairy products from the EU countries has been directed to the USA, China, Saudi Arabia, and North African countries. The export of cheese from the EU countries to Ukraine has also increased up to $30 \%$ over the past year.

The export volume of Ukrainian dairy products to the European market is insignificant. Ukrainian export of dairy products does not use all the possibilities of the tariff quota mechanism, determined by economic agreements with the EU countries. A wide range of products, quality, price and popularity of dairy brands are the main competitive advantages of European dairy products over national products.

One of the main problems of the domestic dairy industry is the low level of state financial support, which is 40-80 times less than in the EU countries. The results of the study and forecasts of the world's leading organizations showed that the volume of the world milk and dairy products market will grow. China, the countries of the Middle East and North Africa will become promising directions of export of dairy products for Ukraine in the near future. The main strategies for the competitive advantages of Ukrainian dairy companies should be the strategy of product diversification and cost reduction.

Key words: production potential, milk processing enterprises, dairy products, milk and dairy products market, export.

\section{References}

NNTs: IAE.

1. Rossokha, V. V. (2009). Formuvannia i rozvytok vyrobnychoho potentsialu ahrarnykh pidpryiemstv. Kyiv:

2. Boikivska, H. (2012). Napriamy pidvyshchennia efektyvnosti vykorystannia vyrobnychoho potentsialu pererobnykh pidpryiemstv systemy APK. Ternopil: Krok.

3. Zapashchuk, L. V. (2010). Metodychni pidkhody do otsinky vyrobnychoho potentsialu promyslovoho pidpryiemstva. Visnyk ZhDTU, (3(53)), 60-63.

4. Tvarynnytstvo Ukrainy. (2019). Kyiv: Derzh. sluzhba statystyky Ukrainy. Retrieved January 09, 2021, from http://ukrstat.gov.ua/druk/publicat/kat_u/2020/zb/05/zb_tvaryny_2019.pdf

5. Vyrobnytstvo promyslovoi produktsii za vydamy. (2019). Kyiv: Derzh. sluzhba statystyky Ukrainy. Retrieved January 09, 2021, from http://ukrstat.gov.ua

6. Ishchuk, S. O., \& Liakhovska, O. V. (2020). Problemy i perspektyvy rozvytku molokopererobnykh vyrobnytstv v Ukraini: rehionalnyi vymir. Lviv.

7. Zovnishnia torhivlia Ukrainy. (2019). Kyiv: Derzh. sluzhba statystyky Ukrainy. Retrieved January 10, 2021, from http://ukrstat.gov.ua/druk/publicat/kat_u/2018/zb/09/zb_sg2019_pdf.pdf.

8. Informatsiino-analitychnyi portal APK Ukrainy. (2020). Retrieved January 09, 2021, from https://agro.me.gov.ua/ua/pidtrimka/tvarinnictvo/stan-finansuvannya-u-2020-roci

9. Agriculture, forestry and fishery statistics. (2020). Statistical Books. Eurostat. Retrieved January 05, 2021, from https://ec.europa.eu/eurostat/documents/3217494/12069644/KS-FK-20-001-EN-N.pdf/a7439b01-671b-80ce-85e4$4 \mathrm{~d} 803 \mathrm{c} 44340 \mathrm{a} ? \mathrm{t}=1608139005821$

10. Rabobank predstavyl top-20 molochnyikh kompanyi myra v 2019 hodu. The Dairy News. Retrieved January 05, 2021, from https://www.dairynews.ru/news/rabobnk-predstavil-top-20-molochnykh-kompaniy-mira.html.

11. TOP - 10 ukrainskykh vyrobnykiv molochnoi produktsii. (2018). MilkUa. Retrieved January 05, 2021, from http://milkua.info/uk/post/top-10-ukrainskih-virobnikiv-molocnoi-produkcii

12. Ukraina mliavo vybyraie kvoty na eksport molochnoi produktsii do YeS. (2019). Ahrotaim. Retrieved January 05, 2021, from https://agrotimes.ua/tvarinnitstvo/ukrayina-mlyavo-vybyraye-kvoty-na-eksport-molochnoyiprodukcziyi-do-yes/

13. Pyrozhok, O. (2019). Dorozhche, nizh u Briusseli: yak ukrainske moloko prohraie Ukrainu vyrobnykam YeS. Ekonomichna Pravda. Retrieved January 09, 2021, from https://www.epravda.com.ua/rus/publications/2019/12/2/654311

14. Chaharovskyi, V. (2020). Shchoroku v Ukraini znykaie 1 velyke molokopererobne pidpryiemstvo. Retrieved January 09, 2021, from https://agropolit.com/interview/748-vadim-chagarovskiy-schoroku-v-ukrayini-znikaye-1-velikemolokopererobne-pidpriyemstvo

15. Dairy and dairy products. (2020). OECD-FAO AGRICULTURAL OUTLOOK 2020-2029. Retrieved January 10, 2021, from http://www.fao.org/3/ca8861en/Dairy.pdf

16. Shahbandeh, M. Leading dairy farming companies worldwide in $2018 / 2019$, based on raw milk production. Retrieved January 05, 2021, from https://www.statista.com/statistics/1124669/leading-dairy-farming-companiesbased-on-milk-production

Цитування згідно ДСТУ 8302:2015

Received 20 January 2021

Approved 3 February 2021 Available in Internet 18.04.2021

Крюкова І.О. Виробничий потенціал молокопереробних підприємств України у контексті євроінтеграційного розвитку // Економіка харчової промисловості. 2021. Т.13, вип. 1. С. 24-29.

Cite as APA style citation

Kryukova, I. (2021). Production potential of milk-processing enterprises of Ukraine in the context of euro-integrated development. Food Industry Economics, 13(1), 24-29. 